\title{
Assessment of potential damage to DNA in urine of coke oven workers: an assay of unscheduled DNA synthesis
}

\begin{abstract}
F Roos, A Renier, J Ettlinger, Y Iwatsubo, M Letourneux, J M Haguenoer, M C Jaurand, J C Pairon
\end{abstract}

Institut National de la Santé et de la Recherche Médicale (INSERM) Unité 139, IM 3, Faculté de Médecine, 8 rue du Général Sarrail, 94010 Créteil cedex, France

F Roos

A Renier

Y Iwatsubo

M C Jaurand

J C Pairon

Service Médical du Travail, Sollac, Dunkerque, France $\mathrm{J}$ Ettlinger

Institut

Interuniversitaire de Médecine du Travail de Paris, Ile de France, Paris, France

Y Iwatsubo

J C Pairon

Institut de Médecine du Travail de Basse

Normandie, Caen,

France

M Letourneux

Institut de Médecine du Travail du Nord, Lille, France

$J M$ Haguenoer

Correspondence to: Dr JC Pairon, INSERM Unité 139 IM3,

Faculté de Médecine, 8 rue du Général Sarrail, 94010 Créteil cedex, France. Tel: 0033149813656

\begin{abstract}
Objectives-A study was conducted in coke oven workers to evaluate the biological consequences of the exposure of these workers, particularly production of potential genotoxic factors.
\end{abstract}

Methods- 60 coke oven workers and 40 controls were recruited in the same iron and steel works. Exposure to polycyclic aromatic hydrocarbons (PAHs) was assessed by job and measurement of 1-hydroxypyrene (10HP) in urine samples. An unscheduled DNA synthesis assay was performed on rat pleural mesothelial cells used as a test system to evaluate the effect of the workers' filtered urine on the DNA repair capacity of rat cells to determine whether DNA damaging agents are present in the urine of these workers. Results-Urinary concentrations of $10 H P$ ranged from 0.06 to 24.2 (mean (SD) 2.1 (3.6)) $\mu \mathrm{mol} / \mathrm{mol}$ creatinine in exposed coke oven workers, and from 0.01 to 0.9 in controls $(0.12(0.15))$. These high concentrations in coke oven workers reflected recent exposure to PAHs and were in agreement with the assessment of exposure by job. No significant difference was found between coke oven workers and controls in the DNA repair level of rat cells treated with urine samples. However, the rat cell repair capacity decreased with increasing 10HP concentrations in the exposed population $(r=-0.28, P<0.05)$.

Conclusions-As high concentrations of 10HP were found in the urine of some workers, a more stringent control of exposures to PAHs in the workplace is required. Exposure to PAHs was not associated with a clear cut modification of the urinary excretion of DNA damaging factors in this test, as shown by the absence of increased unscheduled DNA synthesis in rat cells. However, impairment of some repair mechanisms by urinary constituents is suspected.

(Occup Environ Med 1997;54:854-860)

Keywords: unscheduled DNA synthesis; polycyclic aromatic hydrocarbons; occupational exposure

Coke production entails exposure of workers to high environmental concentrations of airborne pollutants including polycyclic aromatic hydro- carbons (PAHs). Both epidemiological and experimental evidence indicate that $\mathrm{PAHs}$ are carcinogenic in animals and possibly also in humans. Several PAHs - for example, diben$z(a, h)$ anthracene, benzo(a)pyrene-have been shown to induce tumours in numerous test species. ' Exposure to PAHs has long been associated with an excess of various cancers in humans, mainly skin cancers and scrotal cancers, particularly among chimney sweeps. ${ }^{12}$ An increased risk of lung cancer has been reported among workers involved in various industries such as chimney sweeping, aluminium refining, coal gasification, coke production, and in iron and steel foundries. ${ }^{34}$ These compounds are produced during incomplete combustion of natural or synthetic organic materials; they are lipid soluble and can be absorbed into the body through all of the usual routes. Skin and lung routes are predominant in occupational exposure. ${ }^{56}$ The level of exposure to PAHs in the workplace may be evaluated by atmospheric measurement of various PAHs or by measurement of $\mathrm{PAH}$ metabolites in urine. ${ }^{78}$ Thus, the hydroxylated metabolite of pyrene in urine (1-hydroxypyrene, 1OHP) is considered to be a good biological indicator of exposure to PAHs which has the advantage of taking into account the various routes of penetration into the body.

Evaluation of the early consequences of human exposure to carcinogens in the workplace is an important issue. This has led to the development of various assays designed to identify early biological responses. ${ }^{9}$ Recently, many studies have tried to evaluate the biologically effective dose by measuring various markers as surrogates for the target tissue dosenamely, urinary d-glucaric acid as an index of hepatic enzyme activity, ${ }^{10}{ }^{11}$ measurement of sister chromatid exchanges in peripheral lymphocytes, ${ }^{11-14}$ and binding of PAH electrophilic metabolites to DNA in nucleated blood cells or to blood proteins. ${ }^{13}{ }^{15-20}$ Most of these studies were performed in coke oven workers, ${ }^{1012-141819}$ graphite electrode plant workers, ${ }^{1012} 14$ workers exposed to PAHs from bitumen fumes, ${ }^{11}$ and primary aluminium plant and foundry workers. ${ }^{15} 20$ These studies showed contradictory results. Some of them did not show any difference between biological data obtained in subjects exposed to PAHs and in controls - for example, d-glucaric acid, ${ }^{10} 11$ sister chromatid exchanges in peripheral lymphocytes, ${ }^{13}$ antibody to benzo(a)pyrene 
DNA adducts, ${ }^{19}$ and benzo(a)pyrene-albumin adducts. ${ }^{15}$ Other studies reported a significant difference between exposed subjects and controls for some markers-for example, sister chromatid exchanges in peripheral lymphocytes, ${ }^{11} 1214$ benzo(a)pyrene-diol-epoxide (BPDE) adducts to haemoglobin, ${ }^{12}$ PAH-DNA adducts, ${ }^{13} 1720$ and anti-BPDE $(( \pm)-r-7, t-8-$ dihydroxy- $t-9,10$-oxy-7,8,9,10-tetrahydrobenzo(a) pyrene)-DNA adducts. ${ }^{18} \mathrm{~A}$ few authors used urinary mutagenicity-for example, the Ames test, modified nucleosides-to investigate whether body fluids contain factors with a genotoxic potential as a result of occupational exposure..$^{1021}$ In these studies, the urinary mutagenic activity was more likely dependent on smoking habits than on occupational exposure. Nevertheless, a significant effect of occupational exposure was also shown with such assays when tobacco smoking and diet were taken into account.

In the present work, we performed an unscheduled DNA synthesis assay on rat pleural mesothelial cells used as a test system, to evaluate the DNA damaging potency of urine of coke oven workers. Rat pleural mesothelial cells have been shown to be able to metabolise $\mathrm{PAH}$, indicating $P-450$ metabolic activity of these cells. ${ }^{22-24}$ The unscheduled DNA synthesis assay has been previously performed with the same cell type in chromium workers and coal miners. ${ }^{25}{ }^{26}$ In this assay, growth arrested rat cells showed a basal repair rate corresponding to the repair of spontaneously occurring lesions. An enhancement of DNA repair indicates the presence of genotoxic agents producing DNA damage. This repair can be detected by an increase in the amount of radiolabelled nucleoside incorporated into the DNA. By contrast, an impairment of repair mechanisms is associated with a decrease in $\left[{ }^{3} \mathrm{H}\right]$ methyl thymidine $\left(\left[{ }^{3} \mathrm{H}\right] \mathrm{dThd}\right)$ incorporation into DNA.

\section{Materials and methods \\ SUBJECTS}

Urine samples were collected from 60 male coke oven workers (group 1) and 40 male controls recruited in the same steel foundry in Basse Normandie, France. Each subject was asked to fill in a questionnaire providing details on tobacco smoking, alcohol habits, drug consumption, medical history, and work conditions. For 40 of the 60 coke oven workers, a second urine sample was collected three months later, after the end of exposure once the factory was closed. These subjects are included in group 2. Two sets of data were obtained in this group; one provided by urine samples collected during the working period (group 2a), the other one supplied by samples collected after the end of exposure (group 2b). No subject had any known active disease at the time of the study. Subjects receiving chemotherapy, antibiotics, or known metabolic inducers were excluded. Blue collar controls with the same mean age ( \pm 2 years) were selected on the basis of the absence of notable previous occupational exposure to carcinogens, as assessed by the occupational questionnaire. They had similar smoking habits to those of subjects of group 2 .

\section{URINE SAMPLES}

Urine samples were collected in polyethylene flasks at the end of the workshift, after at least five consecutive days of work for group 1 subjects and during routine occupational medical survey for group $2 \mathrm{~b}$ subjects and controls. The samples were frozen at $-20^{\circ} \mathrm{C}$ and kept in the dark until analysis.

EVALUATION OF EXPOSURE TO PAHS

Two methods were used: an assessment of exposure by job by the occupational physician; and measurement of urinary 1-hydroxypyrene (1OHP).

To assess PAH exposure by job, the occupational physician used a standardised questionnaire. Each worker was asked to list his successive jobs throughout his working life, with specific attention being paid to the tasks performed during the week preceding urine collection. This allowed the level of exposure to PAHs to be evaluated, based on concentrations of atmospheric PAHs registered between 1986 and 1990. Atmospheric measurements of PAHs were performed by gas chromatography after collection of individual dynamic samples (during a half shift of four hours) and static samples. This study showed that subjects working on top or near the door of the oven (atmospheric benzo(a)pyrene concentration generally $>10 \mu \mathrm{g} / \mathrm{m}^{3}$ ) presented a high level of exposure (class 1 ), subjects working on the side of the coke oven (atmospheric benzo(a)pyrene concentration generally $1-10 \mu \mathrm{g} / \mathrm{m}^{3}$ ) were exposed to intermediate levels (class 2) and subjects with no direct contact with the oven area (atmospheric benzo(a)pyrene level $<1$ $\mu \mathrm{g} / \mathrm{m}^{3}$ ) were considered to be exposed to low levels (class 3). Two exposure indices were established for each subject: the "last day exposure", corresponding to the class of exposure of the last workshift preceding urine collection; the "week index", obtained by adding the individual scores of all workshifts of the week for a given subject (individual scores of class 1 , class 2 , and class 3 were 3,2 , and 1 , respectively; the week index for a given coke oven worker therefore ranged from 5-15).

Urinary 1OHP was determined by an adaptation of the method of Jongeneelen et al. ${ }^{7}$ The technique included enzymatic hydrolysis of the conjugates with a mixture of glucuronidase and sulphatase followed by chromatography on octadecyl silica cartridges (Bond-Elut $500 \mathrm{mg}$, Analytichem, Harbor City, CA, USA) performed with a Vac Elut SPS 24 from Varian previously activated with methanol and distilled water. Samples were then extracted with methanol, dried with an evaporator, and then resuspended in $200 \mu \mathrm{l}$ acetonitrile. A second chromatography was performed on a Nucleosil $10 \mathrm{C} 18$ column with an isocratic elution (distilled water: acetonitrile; $60: 40 \mathrm{v} / \mathrm{v}$ ) at a flow rate of $1 \mathrm{ml} / \mathrm{min}$. The high performance liquid chromatography system was 9000 Varian including two 9010 Varian pumps. The retention time of $1 \mathrm{OHP}$ was found to be six 
minutes. 1-Hydroxypyrene concentrations were measured by fluorimetry (excitation $240 \mathrm{~nm}$, emission $390 \mathrm{~nm}, 821$-FP JASCO spectrofluorometer). The procedure was regularly calibrated with aliquots of $0.1 \mu \mathrm{g} / 1$ to $20.0 \mu \mathrm{g} / 1$ of $1 \mathrm{OHP}$ in the elution medium (Aldrich, Paris). An external standard was regularly chromatographed to assess the validity of the procedure. The detection limit was $0.1 \mu \mathrm{g} / 1$ and the results were standardised to urinary creatinine.

\section{UNSCHEDULED DNA SYNTHESIS ASSAY}

Rat pleural mesothelial cells were cultured in 24 well cluster culture dishes (Costar) ${ }^{24}$ Eighty thousand cells were seeded per well in complete medium. The cells grew as a monolayer and reached confluence after four days of incubation; the medium was then replaced with Roswell Park Memorial Institute (RPMI) medium containing $1 \%$ fetal calf cells ( $5 \mathrm{mM}$, hydroxy urea (HU) $100 \mathrm{U} / \mathrm{ml}$ penicillin, and 50 $\mu \mathrm{g} / \mathrm{ml}$ streptomycin. The cells were incubated for 24 hours at $37^{\circ} \mathrm{C}$ in a humidified atmosphere of $5 \% \mathrm{CO}_{2}$ in air then incubated for 24 hours in RPMI medium containing $1 \%$ fetal calf cells ( $5 \mathrm{mM} \mathrm{HU}$ ) and $4 \mu \mathrm{Ci} / \mathrm{ml}$ $\left[{ }^{3} \mathrm{H}\right] \mathrm{dThd}$ (specific activity: 50 to $60 \mathrm{Ci} / \mathrm{mmol}$ ), with or without urine. A laboratory reference (an RPMI medium containing $500 \mu \mathrm{g} / \mathrm{ml}$ crocidolite fibres) was used to check the response of rat cells. Crocidolite fibres produce a considerable enhancement of DNA repair in rat cells due to DNA damage. ${ }^{24}$ The urine samples were previously filtered through Amicon membrane filters YM 10 according to Emerit $e t a l^{7}$ and the volume added to each well was adjusted to initial urinary creatinine (maximum volume $20 \mu \mathrm{l}$ ). The cells were then washed three times with phosphate buffered saline. Acid soluble material was removed by rinsing the cell layer with $10 \%$ cold trichloroacetic acid for 10 minutes, followed by incubation in a mixture of $0.2 \mathrm{M} \mathrm{NaOH}$ and $1 \%$ sodium dodecyl sulphate. Aliquots $(200 \mu \mathrm{l})$ were placed in vials and scintillation fluid (Ultima Gold MV, Packard) was added. Radioactivity was determined on a Beckman LS 6000 SC apparatus. The DNA cell content was assessed by fluorometric assay. ${ }^{28}$ Fluorescence was measured with a Millipore Cytofluor 2350. The cell repair capacity was evaluated from the ratio of $\left[{ }^{3} \mathrm{H}\right] \mathrm{dTh}$ incorporation $(\mathrm{dpm}) / \mu \mathrm{g}$ DNA in each well. Results of the unscheduled DNA synthesis assay were expressed as the ratio of the repair capacity of rat cells treated with urine to that of untreated cells in RPMI medium.

\section{MTT ASSAY}

The purpose of this test was to control the viability of rat cells after treatment with urine samples. The 3-[4,5-dimethylthiazol-2-YL] -2,5-diphenyltetrazolium bromide (MTT) is reduced into formazan by mitochondrial dehydrogenases. This reduction can only occur in active cells. The quantity of formazan is directly proportional to the number of viable cells. $^{29}$ Rat pleural mesothelial cells were cultured in 96 well cluster culture dishes (Costar) in complete medium. After confluence, the cells were treated with the filtered urine samples, or crocidolite, or cultured in RPMI medium, as in the unscheduled DNA synthesis assay. Five wells were used for each treatment. The cells were incubated for 24 hours under the same conditions as for the unscheduled DNA synthesis assay. To each well MTT solution $(40 \mu \mathrm{l}, 2 \mathrm{mg} / \mathrm{ml})$ was then added. After three hours of incubation $\left(37^{\circ} \mathrm{C}\right.$ in a humidified atmosphere, $5 \% \mathrm{CO}_{2}$ ), the supernatant was carefully removed and the formazan crystals were dissolved by addition of $200 \mu \mathrm{l}$ dimethyl sulphoxide. The cluster culture dishes were agitated for two minutes with a multidish agitator and the optical density was measured by spectrophotometry at $540 \mathrm{~nm}$. The mean optical density of the five replicate wells was calculated for each treatment. Results were expressed as the ratio of the mean obtained for each group to the mean obtained for samples in the same dish in RPMI medium (optical density in urine treated rat cells/ optical density in untreated rat cells).

DETERMINATION OF COTININE IN URINE SAMPLES Cotinine is a metabolite of nicotine, which can be used to evaluate the last two days of individual nicotine intake in smokers, taking into account various parameters, such as tobacco strength, duration of inhalation, filtered or unfiltered cigarettes. Cotinine was evaluated by an automated colorimetric method on COBAS-BIO with $1 \%$ barbituric acid derived from the manual method of Peach et al. ${ }^{30}$ Results were expressed in relation to urinary creatinine.

\section{STATISTICAL ANALYSIS OF RESULTS}

The relation between PAH exposure and cell repair capacity was examined by two methods: comparison of the $\left[{ }^{3} \mathrm{H}\right] \mathrm{dTh}$ incorporation / DNA ratio between exposure groups; and correlation of this ratio with urinary $1 \mathrm{OHP}$.

Three types of comparisons were carried out between exposure groups: coke oven workers during exposure versus controls (group $1 v$ controls); coke oven workers after the end of exposure versus controls (group $2 \mathrm{~b} v$ controls); coke oven workers during exposure versus coke oven workers after cessation of exposure (groups $2 \mathrm{a} v 2 \mathrm{~b}$ ). Coke oven workers and controls were compared by $\chi^{2}$ test and Student's $t$ test for univariate analysis. A paired $t$ test was used to examine the variables of coke oven workers before and after the end of exposure.

Similar comparisons were carried out for the MTT test.

Relations between urinary 1OHP and other biological variables were examined by Pearson's correlation coefficients and adjustment for tobacco smoking was made with urinary cotinine by multiple linear regression.

All statistical analyses were performed with the SAS package. ${ }^{31}$

\section{Results}

Table 1 shows the characteristics of the subjects included in the study (age, smoking habits) and the urinary cotinine and creatinine of these subjects. Coke oven workers and con- 
Table 1 Sociodemographic characteristics of the study population and biological indices of tobacco smoking

\begin{tabular}{|c|c|c|c|c|}
\hline \multirow[b]{2}{*}{ Variables } & \multicolumn{3}{|l|}{ Coke oven workers } & \multirow{2}{*}{$\frac{\text { Controls }}{(n=40)}$} \\
\hline & Group $1(n=60)$ & Group $2 a(n=40)$ & Group $2 b(n=40)$ & \\
\hline \multicolumn{5}{|l|}{ Age (y): } \\
\hline Mean (SD) & $40.9(8.6)$ & $43.2(6.3)$ & & $41.7(8.8)$ \\
\hline Median (range) & $43(19-51)$ & $44.5(28-51)$ & & $44.5(21-51)$ \\
\hline \multicolumn{5}{|l|}{ Smoking habits: } \\
\hline Current smokers (n (\%)) & $30 \quad(50)$ & $16 \quad(40)$ & & $18 \quad(45)$ \\
\hline Former smokers (n (\%)) & $16 \quad(26.7)$ & $13(32.5)$ & & $11 \quad(27.5)$ \\
\hline Non-smokers (n (\%)) & $14 \quad(23.3)$ & $11(27.5)$ & & $11 \quad(27.5)$ \\
\hline \multicolumn{5}{|l|}{ Urinary creatinine $(\mathrm{mmol} / \mathrm{l})$ : } \\
\hline Mean (SD) & $14.1(6.7)$ & $13.8(6.7)$ & $16.5(8.9)$ & $11.7(0.6)$ \\
\hline Median(range) & $13.9(1.2-32.4)$ & $13.5(3.5-32.4)$ & $15.9(5.8-45.1)$ & $11.3(2.7-24.7)$ \\
\hline \multicolumn{5}{|c|}{ Urinary cotinine ( $\mathrm{mmol} / \mathrm{mol}$ creatinine): } \\
\hline Mean (SD) & $2.7(3.1)$ & $2.0(2.5)$ & $2.0(2.6)$ & $3.2(4.3)$ \\
\hline Median (range) & $1.1(0-10.9)$ & $0.5(0-8.8)$ & $0.5(0-8.6)$ & $0.9(0-18.3)$ \\
\hline
\end{tabular}

trols were similar for age, smoking, and alcohol habits. Twenty per cent of subjects consumed drugs. No significant difference was found between coke oven workers and controls for urinary variables, except in group $2 b$, in which urinary creatinine was higher than in controls.

The urinary cotinine concentration was considered to reflect current smoking consumption, whereas $1 \mathrm{OHP}$ was considered to be representative of exposure to PAHs. Coke oven workers had higher urinary $1 \mathrm{OHP}$ concentrations than controls, even after adjustment for urinary cotinine (fig 1). After three months without occupational exposure, the urinary 1OHP concentrations were similar in coke oven workers and in controls. There was a good agreement between urinary $1 \mathrm{OHP}$ values and $\mathrm{PAH}$ exposure levels as defined by the assessment of exposure by job. Coke oven workers with high exposure (class 1 ) during the last shift before urine collection had higher $10 H P$ concentrations than less exposed subjects (class 2 and class 3 subjects), even after taking urinary cotinine concentration into account (median values, mean (SD) 3.7 (5.6 (6.5)), $1.3(1.7(1.2))$ and $0.6(1(0.8)) \mu \mathrm{mol}$ $1 \mathrm{OHP} / \mathrm{mol}$ creatinine for class 1 , class 2 , and class 3 subjects, respectively; $P<0.001$ ). The urinary $1 \mathrm{OHP}$ value was strongly correlated with the week index $(r=0.52 ; \mathrm{P}=0.001)$, even when smoking habits were taken into account.

Table 2 shows the results of DNA repair capacity and viability (MTT test) of rat cells treated with urinary filtrates. No significant difference was found for $\mathrm{dpm} / \mathrm{DNA}$ values between group 1 workers and controls, or between coke oven workers before (group 2a) and after the end of exposure (group 2b) regardless of smoking status (fig 2). Similar results were found when analysis was restricted to comparison between subjects with the highest level of exposure and controls. This lack of significant change was not due to a dysfunction of rat cells used as a test system, as $\left[{ }^{3} \mathrm{H}\right] \mathrm{dTh}$ incorporation was higher in the cells treated with crocidolite (mean $(S D)=8420$ (751) $\mathrm{dpm} / \mu \mathrm{g}$ ) than in the untreated cells (mean $(\mathrm{SD})=7687(1079) \mathrm{dpm} / \mu \mathrm{g}) \quad(\mathrm{P}<0.001)$, as expected.

The viability of rat cells treated with urine samples from coke oven workers was slightly altered (although not significantly; $\mathrm{P}=0.08$ ) in comparison with urine from controls. This phenomenon was found both for samples collected during working activity and after three months without occupational exposure. Viability of rat cells treated with crocidolite was decreased to $89.9 \%$ compared with untreated rat cells $(P<0.001)$.

The correlation between DNA repair capacity of rat cells and individual biological variables showed a reduction of incorporation of $\left[{ }^{3} \mathrm{H}\right] \mathrm{dTh}$ which depended on the urinary $1 \mathrm{OHP}$ concentration in $\mathrm{G} 1$ workers $(r=-0.28$, $\mathrm{P}=0.05)$. This reduction cannot be attributed to a loss of cell viability, as the viability of rat cells was not significantly modified by urine treatment. Moreover, crocidolite reduced the

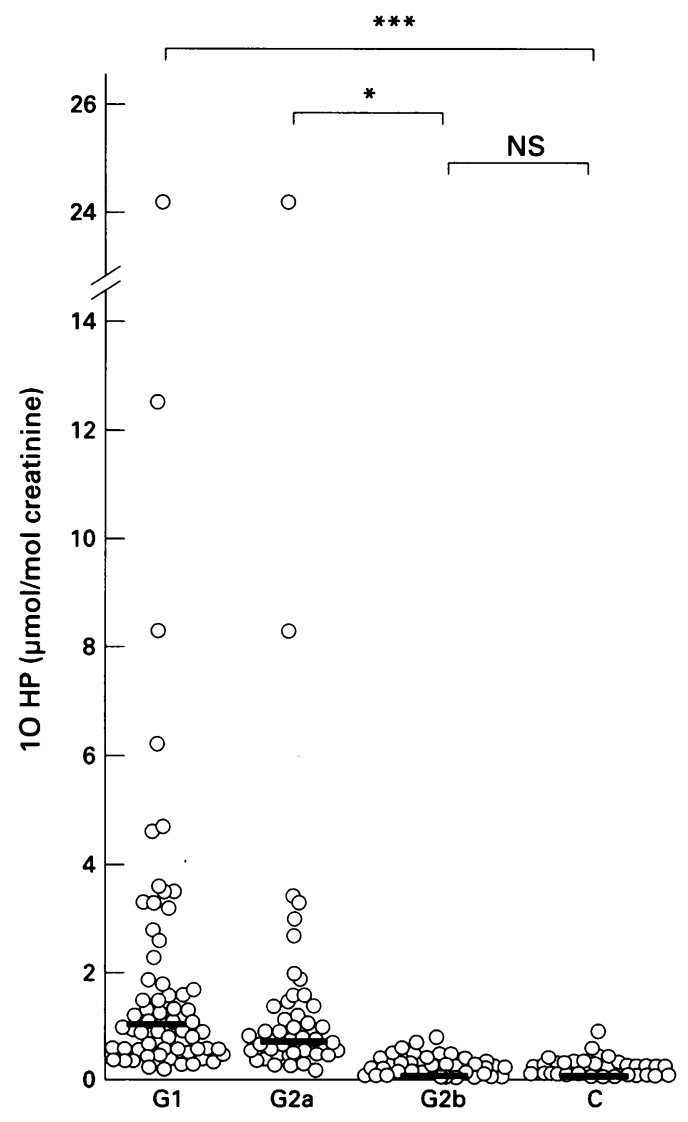

Figure 1 Determination of urinary 1OHP. Each open circle represents the individual value of urinary $1 O H P$ of a given subject. Black horizontal bar represents median for each group of workers. $1 O H P=1$ hydroxypyrene. $G 1=60$ coke oven workers, urine collection during the working period; $G 2=a$ second urine sample was collected three months after closure of the factory in 40 of the 60 coke oven workers; $G 2 a=$ samples collected during the working period; $G 2 b=$ samples collected after the end of exposure; $C=b l u e$ collar controls. ${ }^{\star} p<0.05 ; * \star * p<0.001$. 


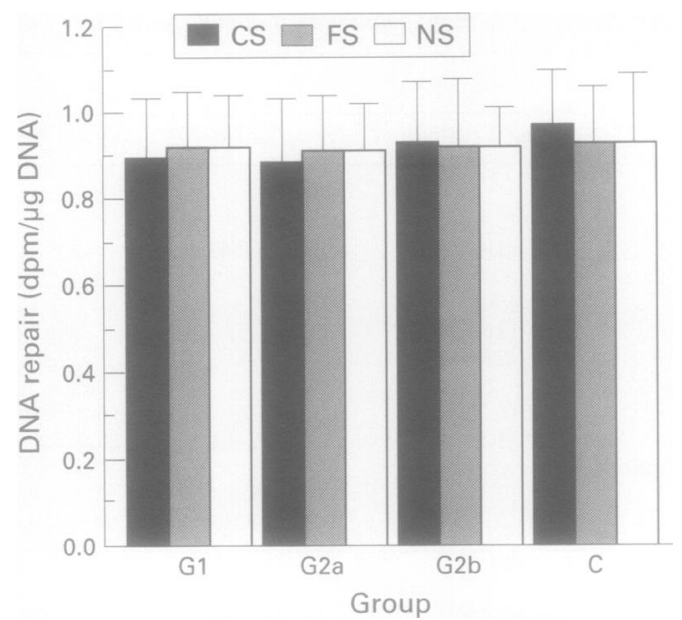

Figure $2 D N A$ repair in rat pleural mesothelial cells treated with urine from coke oven workers or blue collar controls according to smoking habits. Results of the unscheduled DNA synthesis assay were expressed as the ratio of the repair capacity of rat cells treated with urine from coke oven workers or controls to that of untreated cells (RPMI medium control). G1=60 coke oven workers, urine collection during the working period; $G 2=a$ second urine sample was collected three months after closure of the factory in 40 of the 60 coke oven workers; $G 2 a=$ samples collected during the working period; $G 2 b=$ samples collected after the end of exposure; $C=$ blue collar controls; $C S=$ current smokers; $F S=$ former smokers; $N S=$ nonsmokers. There was no significant difference for $\operatorname{dpm} / \mathrm{DN} A$ values between groups of workers, whatever the smoking status.

cell viability but enhanced DNA repair. By contrast, there was no correlation between DNA repair capacity of rat cells and urinary cotinine ( $r=-0.20, \mathrm{NS})$, or between DNA repair capacity and results of viability of rat cells $(r=-0.06, \mathrm{NS})$ in group 1 subjects. The DNA repair capacity of rat cells was not correlated with any of these variables in group $2 \mathrm{~b}$ subjects or in controls.

No correlation between rat cells viability and urinary cotinine or 1OHP concentrations was found in any of the groups.

\section{Discussion}

This study was designed to assess whether urinary filtrates from subjects with various levels of occupational exposure to PAH were able to induce DNA damage or modify DNA repair processes in rat cells used as a test system. An enhancement of DNA repair would indicate that the urine filtrates contain clastogenic molecules; a decrease in DNA repair would suggest the presence of compounds able to impair repair processes.

Exposure to PAHs was evaluated according to the levels of an internal dose indicator, urinary 1OHP, and by an assessment of exposure by job by the occupational physician. 1-Hydroxypyrene is a non-mutagenic metabo- lite which can be found in the urine of humans exposed to PAHs. Its concentration in biological fluids cannot be used to evaluate the carcinogenic risk for exposed workers, which probably depends on the various PAH profiles of pitch and tar volatiles polluting the work environment. However, because of the very good correlation between PAH concentrations in the work environment and urinary 1OHP concentrations, ${ }^{32-34}$ this metabolite has been proposed as a biological indicator of occupational exposure to PAHs. ${ }^{85}$ Moreover, this metabolite shows exposure to pyrene independently of the route of exposure. ${ }^{32}{ }^{36}$ The values of urinary 1OHP found in the present study were in the range $0.01-24.2 \mu \mathrm{mol} / \mathrm{mol}$ creatinine and are consistent with those reported by other authors in workers with similar occupations. ${ }^{8122132}$ Moreover, a fairly good correlation was found between 1OHP and the week exposure index, confirming that this variable is a good marker of recent exposure. The urinary $10 \mathrm{HP}$ concentrations were also lower three months after the end of occupational exposure and were similar to control concentrations. This is in agreement with the half life of this metabolite, which is about 18 hours. ${ }^{8}$ The urinary 1 OHP concentration is considered to be influenced by smoking habits only in the case of low occupational exposure to PAHs. ${ }^{86-38}$ Thus, as some of the exposed workers had a low exposure during the week preceding collection of the urine sample and as smoking habit is a confounding factor, we selected controls with similar smoking habits. This allowed evaluation of the true effect of occupational exposure on the DNA repair capacity of rat cells treated with urine from these workers. The effect of diet, particularly fried or grilled meat, may affect the urinary excretion of $10 \mathrm{HP} .^{36}{ }^{39}$ Although eating behaviour was not controlled in our study, results of 1OHP were consistent with the evaluation of the level of exposure of the last workshift, as assessed by job by the occupational physician. We therefore consider that diet had a minimal influence in our population compared with that of occupation.

The DNA repair assay has been previously performed on rat cells with concentrated urine samples from subjects exposed to suspected or known genotoxic agents. ${ }^{25} \mathrm{~A}$ clastogenic activity was shown in rat cells treated with urine from chromium workers and patients receiving radiotherapy with or without chemotherapy for cancer. ${ }^{25}$ Emerit $e t a l^{77} 4041$ showed the presence of clastogenic factors in various biological samples (plasma, synovial fluid, cerebrospinal fluid) from patients with congenital

Table 2 Mean (SD) values of DNA repair and viability of rat cells treated with urine filtrates

\begin{tabular}{|c|c|c|c|c|}
\hline \multirow[b]{2}{*}{ Variable } & \multicolumn{3}{|c|}{ Coke oven workers } & \multirow[b]{2}{*}{$\begin{array}{l}\text { Controls } \\
(n=40)\end{array}$} \\
\hline & $\begin{array}{l}\text { Group } 1 \\
(n=60)\end{array}$ & $\begin{array}{l}\text { Group } 2 a \\
(n=40)\end{array}$ & $\begin{array}{l}\text { Group 2b } \\
(n=40)\end{array}$ & \\
\hline \multicolumn{5}{|l|}{ DNA repair: } \\
\hline$\left[{ }^{3} \mathrm{H}\right] \mathrm{dTh}$ incorporation (dpm) & $0.89(0.10)$ & $0.89(0.10)$ & $0.90(0.09)$ & $0.91(0.11)$ \\
\hline DNA $(\mu \mathrm{g})$ & $0.99(0.07)$ & $1.0(0.07)$ & $0.98(0.07)$ & $0.97(0.07)$ \\
\hline$\left[{ }^{3} \mathrm{H}\right] \mathrm{dThd}$ incorporation/DNA (dpm/ $\mu \mathrm{g}$ DNA) & $0.90(0.13)$ & $0.90(0.13)$ & $0.92(0.13)$ & $0.95(0.14)$ \\
\hline Viability (MTT test) OD $(540 \mathrm{~nm})$ & $0.94(0.12)$ & $0.93(0.14)$ & $0.92(0.12)$ & $0.99(0.13)$ \\
\hline
\end{tabular}


breakage syndromes such as ataxia telangiectasia and Bloom's syndrome, as well as chronic inflammatory diseases such as rheumatoid arthritis, systemic lupus erythematosus, and progressive systemic sclerosis. Most of the clastogenic factors isolated to date have a molecular weight lower than $10000 \mathrm{Da}$ - such as 4-hydroxynonenal (150 Da) or inosine triphosphate $(388 \mathrm{Da})$. Our urine filtration procedure allowed collection of these factors in our filtrates. Incorporation of $\left[{ }^{3} \mathrm{H}\right] \mathrm{dTh}$ Thas significantly enhanced in cells treated with crocidolite, compared with untreated cells, attesting that our test system responded accordingly. Results obtained with urine samples from coke oven workers were unexpected, as the results obtained by Pillière $e t a l^{25}$ with urine samples from chromium workers suggested that this urine enhanced DNA repair in rat cells indicated the presence of clastogenic factors in urine as in other fluids. ${ }^{40}$ By contrast, in our study, we found a tendency for less incorporation of $\left[{ }^{3} \mathrm{H}\right] \mathrm{dTh}$ in the cells treated with urine samples from exposed coke oven workers when $10 H P$ was increased. These results cannot be explained by smoking habits (as assessed by urinary cotinine), or by urinary concentration, as the volume was adjusted in each well according to the initial concentration. An impairment of cell viability is also unlikely.

The different results obtained for DNA repair capacity of rat cells treated with urine from chromium workers and from coke oven workers suggests that subjects exposed to different types of carcinogens excrete different compounds in urine. Urine samples from populations exposed to chromium derivatives might therefore enhance DNA repair of rat cells as a result of DNA breakage, whereas other urine samples might decrease the cell's ability to repair DNA. This tendency was suggested by the results obtained by Knudsen et $a l .{ }^{42}$ These authors showed that unscheduled DNA synthesis in peripheral lymphocytes induced by $\mathrm{N}$-acetoxy- $\mathrm{N}$-acetylaminofluorene was decreased in welders compared with a reference population. Exposure to mutagenic or carcinogenic agents may therefore lead to the formation of factors inhibiting DNA repair, an effect that might account for the accumulation of errors in DNA integrity.

Although the biological response found in the DNA repair assay performed on rat cells treated with urine filtrates from coke oven workers was only moderate, urinary $1 \mathrm{OHP}$ concentrations indicated that exposure to PAHs was excessive in this population. Urine from coke oven workers also exhibited some inhibitory effect on the DNA repair capacity of rat cells. More stringent control of exposure is therefore required in the workplace.

We are indebted to the coke oven workers who agreed to participate in the study, to Anne Philibert and Chantal Cordie for their helpful contribution in the collection of biological samples, to Francois Bureau for his contribution to the measurement of creatinine, to Gaspard Gohin for his participation in preparation of urine samples, to Marie-Claudine Jacquetion in preparation of urine samples, to Marie-Claudine Jacquemont for her contribution to measurement of urinary 1OHP and to Dr Claude Philippon for urinary cotinine measurement This work was supported by a grant from the
1 International Agency for Research on Cancer. Polynuclear aromatic compounds, chemical, environmental and experimental data. IARC Monogr Eval Carcinog Risks Hum mental data. LAR

2 International Agency for Research on Cancer. Certain polycyclic aromatic hydrocarbons and heterocyclic compounds. IARC Monogr Eval Carcinog Risks Hum 1973;3:1-271.

3 International Agency for Research on Cancer. Polynuclear aromatic compounds, industrial exposures in aluminium production, coal gasification, coke production, and iron and steel foundries. IARC Monogr Eval Carcinog Risks Hum and steel foundries.

4 Costantino JP, Redmond CK, Bearden A. Occupationally related cancer risk among coke oven workers: 30 years of follow-up. F Occup Environ Med 1995;37:597-604

5 Van Rooij JGM, Van Lieshout EMA, Bodeliere-Bade MM, Jongeneelen FJ. Effect of the reduction of skin contamination on the internal dose of creosote workers exposed to polycyclic aromatic hydrocarbons. Scand $\mathcal{f}$ Work Environ Health 1993;19:200-7.

6 Quinlan R, Kowalczyk G, Gardiner K, Calvert I. Exposure to polycyclic aromatic hydrocarbons in coal liquefaction workers: impact of a workwear policy on excretion of workers: impact of a workwear policy on excretion of urinary

7 Jongeneelen FJ, Anzion RBM, Hendeson PT. Determination of hydroxylated metabolites of polycyclic aromatic hydrocarbons in urine. $f$ Chromatogr 1987;413:227-32.

8 Buchet JP, Gennart JP, Mercado-Calderon F, Delavignette JP, Cupers L, Lauwerys R. Evaluation of exposure to polycyclic aromatic hydrocarbons in a coke production and a graphite electrode manufacturing plant: assessment of urinary excretion of 1-hydroxypyrene. Br f Ind Med 1992;49: 761-8.

9 Knudsen L, Sorsa M. Human biological monitoring of occupational genotoxic exposures. Pharmacol Toxicol 1993; occupational genot

10 Ferreira Jr M, Buchet JP, Burrion JB, Moro J, Cupers L, Delavignette JP, et al. Determinants of urinary thioethers, D-glucaric acid and mutagenicity after exposure to polycyclic aromatic hydrocarbons assessed by air monitoring and measurement of 1-hydroxypyrene in urine: a cross sectional study in workers of coke and graphite-electrode-producing plants. Int Arch Occup Environ Health 1994;65:329-38.

11 Hatiian BA, Edwards JW, Harrison J, Williams FM, Blain P. Ambient, biological, and biological effect monitoring of exposure to polycyclic aromatic hydrocarbons (PAHs). Toxicol Lett 1995;77:271-9.

12 Buchet JP, Ferreira M, Burrion JB, Leroy T, Kirsch-Volders $M$, Van Hummelen $\mathrm{P}$, et al. Tumor markers in serum, polyamines and modified nucleosides in urine and cytogenetic aberrations in lymphocytes of workers exposed to polycyclic aromatic hydrocarbons. Am f Ind Med 1995;27: 523-43.

13 Popp W, Vahrenholz C, Schell C, Kraus R, Bülow JV, Müller G, Norpoth K. Risk estimation in coke-oven workers by determining some biomarkers of carcinogen exposure. Exp Toxicol Pathol 1995;47:440-2.

14 Van Hummelen P, Gennart JP, Buchet JP, Lauwerys R, Kirsch-Volders $M$. Biological markers in PAH exposed workers and controls. Mutat Res 1993;300:231-9.

15 Omland $\emptyset$, Sherson D, Hansen AM, Sigsgaard T, Autrup $\mathrm{H}$, Overgaard E. Exposure of iron foundry workers to polycyclic aromatic hydrocarbons: benzo(a)pyrene-albumin adducts and 1-hydroxypyrene as biomarkers for exposure. Occup Environ Med 1994;51:513-8.

16 Ferreira Jr M, Tas S, Dell'Omo M, Goormans G, Buchet JP, Lauwerys R. Determinants of benzo(a)pyrenediol epoxide adducts to haemoglobin in workers exposed to polycyclic aromatic hydrocarbons. Occup Environ Med 1994;51:4515.

17 Perera FP, Dickey C, Santella R, O'Neill JP, Albertini RJ, Ottman $R$, et al. Carcinogen-DNA adducts and gene mutaOttman $R$, et al. Carcinogen-DNA adducts and gene muta-
tion in foundry workers with low-level exposure to polycytion in foundry workers with low-level exposure to polycy-
clic aromatic hydrocarbons. Carcinogenesis 1994;15:2905clic 10.

18 Rojas M, Alexandrov K, Auburtin G, Wastiaux-Denamur A, Mayer L, Mahieu B, et al. Anti-benzo(a)pyrene diolepoxide-DNA adduct levels in peripheral mononuclear cells from coke oven workers and the enhancing effect of smoking. Carcinogenesis 1995;16:1373-6.

19 Øvrebo S, Haugen A, Farmer PB, Anderson D. Evaluation of biomarkers in plasma, blood, and urine samples from coke oven workers: significance of exposure to polycyclic aromatic hydrocarbons. Occup Environ Med 1995:52:7506.

20 Van Schooten FJ, Jongeneelen FJ, Hillebrand MIX, Van Leeuwen FE, De Looff AJA, Dijkmans APG, et al. PolycyLeeuwen FE, De Looff AJA, Dijkmans APG, et al. Polycyclic aromatic hydrocarbon-DNA adducts in white blood cell DNA and 1-hydroxypyrene in the urine from
aluminium workers: relation with job category and aluminium workers: relation with job category and synergistic effect of

21 Clonfero E, Granella M, Marchioro M, Leopardi Barra E, Nardini $\mathrm{B}$, et al. Urinary excretion of mutagens in coke oven workers. Carcinogenesis 1995;16:547-54.

22 Bastie-Sigeac I, Hubert-Habart M, Jaurand MC, Bignon J. Métabolisme du benzo(a)pyrene par des cellules mésothéliales de rat en culture. CR Acad Sci III 1984;298 423-6.

23 Buard A, Beaune PH, Renier A, Jaurand MC, Bignon J, Laurent P. Expression of cytochrome P450 in rat pleural mesothelial cells in secondary cultures $\mathcal{F}$ Cell Physiol 1994; 160:176-84. 
24 Renier A, Levy F, Pilliere F, Jaurand MC. Uncheduled DNA synthesis in rat pleural mesothelial cells treated with mineral fibres or benzo(a)pyrene. Mutat Res 1990;241 361-7.

25 Pilliere F, Levy F, Renier A, Brochard P, Jaurand MC Induction of DNA-repair synthesis (UDS) in rat pleural mesothelial cells by urine of subjects exposed to genotoxic agents. F Toxicol Clin Toxicol 1992;30:223-38.

26 Frette C, Renier A, Pairon JC, Pham QT, Bertrand JP, Oryszyn MP, et al. Clastogenic potential of urine from Lorraine coal miner assessed by the in vitro measurement of raine coal miner assessed by the in vitro measurement of DNA repair in rat pleural mesothelial cells (RPMC). ERS annual congress, Nice, France,
Respir $\mathcal{7} 1994 ; 7$ (suppl 18):378S.

27 Emerit I, Levy A, Pagano G, Pinto L, Calzone R, Zatterale A. Transferable clastogenic activity in plasma from patients with Fanconi anemia. Hum Genet 1995;96:14-20.

28 Rago R, Mitchen J, Wilding G. DNA fluorometric assay in 96-well tissue culture plates using Hoechst 33258 after cell lysis by freezing in a distilled water. Anal Biochem 1990;191:31-4.

29 Mosmann BT. Rapid colorimetric assay for cellular growth and survival: application to proliferation and cytotoxicity and sur. F Immun Methods 1983;65:55-63.

30 Peach H, Ellard GA, Jenner PJ, Morris RW. A simple inexpensive urine test of smoking. Thorax 1985;40:351-7.

31 SAS Institute. SAS/STAT user's guide, release 6.03 edition. Cary, NC: SAS Institute, 1988

32 Jongeneelen FJ, Van Leeuwen FE, Oosterink S, Anzion RBM, Van der Loop F, Bos RP, Van Veen HG. Ambient and biological monitoring of coke oven workers: determinants of the internal dose of polycyclic aromatic hydrocarbons. Br F Ind Med 1990;47:454-61.

33 Tolos WP, Shaw PB, Lowry LK, Mackenzie BA, Dend JF, Markel HL 1-pyrenol: a biomarker for occupational exposure to polycyclic aromatic hydrocarbons. Appl Occup Environ Hyg 1990;5:303-9.
34 Hansen AM, Omland O, Poulsen OM, Sherson D, Digsgaard T, Christensen JM, Overgaard E. Correlation between work process-related exposure to polycyclic aromatic hydrocarbons and urinary levels of $\alpha$-naphthol , B-naphthylamine and 1-hydroxypyrene in iron foundry workers. Int Arch Occup Environ Health 1994;65:385-94.

35 Jongeneelen FJ. Biological exposure limit for occupational exposure to coal tar pitch volatiles at cokeovens. Int Arch Occup Environ Health 1992;63:511-6.

36 Van Rooij JGM, Veeger MMS, Bodeliere-Bade MM, Scheepers PTJ, Jongeneelen FJ. Smoking and dietary intake of polycyclic aromatic hydrocarbons as sources of interindividual variability in the baseline excretion of 1-hydroxypyrene in urine. Int Arch Occup Environ Health 1994;66:55-65.

37 Jongeneelen FJ, Bos RP, Henderson PT. Metabolites of polycyclic aromatic hydrocarbons in urine of exposed workers. Toxicol Environ Chem 1988;16:295-307.

38 Granella $M$, Clonfero E. Urinary excretion of 1-pyrenol in automative repair workers. Int Arch Occup Environ Health 1993;65:241-5.

39 Buckley TJ, Lioy PJ An examination of the time course from human dietary exposure to polycyclic aromatic hydrocarbons to urinary elimination of 1-hydroxypyrene. Br F Ind Med 1992;49:1 13-24

40 Emerit I. Chromosome breakage factors: origin and possible significance. Progress in Mutation Research 1982;4:61-74.

41 Emerit I. Reactive oxygen species, chromosome mutation, and cancer. Possible role of clastogenic factors in carcinogenesis. Free Radic Biol Med 1994;16:99-109.

42 Knudsen L, Boisen T, Christensen JM, Jelnes JE, Jensen $\mathrm{GE}$, Jensen JC, et al. Biomonitoring of genotoxic exposure among stainless steel welders. Mutat Res 1992;279:129 43.

\section{Vancouver style}

All manuscripts submitted to Occup Environ Med should conform to the uniform requirements for manuscripts submitted to biomedical journals (known as the Vancouver style.)

Occup Environ Med, together with many other international biomedical journals, has agreed to accept articles prepared in accordance with the Vancouver style. The style (described in full in the $\mathcal{F} A M A[1]$ ) is intended to standardise requirements for authors, and is the same as in this issue.

References should be numbered consecutively in the order in which they are first mentioned in the text by Arabic numerals on the line in square brackets on each occasion the reference is cited (Manson[1] confirmed other reports[2][3][4][5]). In future references to papers submitted to Occup Environ Med should include: the names of all authors if there are seven or less or, if there are more, the first six followed by et al; the title of journal articles or book chapters; the titles of journals abbreviated according to the style of Index Medicus; and the first and final page numbers of the article or chapter. Titles not in Index Medicus should be given in full.

Examples of common forms of references are:

1 International Committee of Medical Journal Editors. Uniform requirements for manuscripts submitted to biomed journals. $7 A M A$ 1993;269:2282-6.

2 Soter NA, Wasserman SI, Austen KF. Cold urticaria: release into the circulation of histmaine and eosinophil chemotactic factor of anaphylaxis during cold challenge. N Engl f Med 1976;294:687-90.

3 Weinstein L Swartz MN. Pathogenic properties of invading micro-organisms. In: Sodeman WA Jr, Sodeman WA, ing micro-organisms. In: Sodeman WA Jr, Sodeman WA,
eds. Pathologic physiology, mechanisms of disease. Philadeleds. Pathologic physiology, mechanism
phia: W B Saunders, 1974:457-72. 